\title{
A pro-competitive order as an institute of the economy based on knowledge
}

\author{
Elena Rozhdestvenskaya ${ }^{1 \mathrm{a}}$ \\ ${ }^{1}$ Tomsk Polytechnic University, 634050 Lenin Avenue, 30, Tomsk, Russia
}

\begin{abstract}
The modern theory of constitutional economy returns to the ideas of the founders of ordoliberalism, marks the function of the state as an institutional mechanism to promote and protect competition. The role of the state is the system subject of a pro-competitive order. The article analyzes the patterns of spontaneous transformation of government involvement in the market economy in the procompetitive order Institute as a condition of sustainable development of the economy based on knowledge. The research results are useful in the development of the theory of regulation of market processes and the formation of a strategic state policy in the field of economic regulation, in particular for Russia.
\end{abstract}

\section{Introduction}

The main trend in the development of the scientific and economic knowledge is the transition from the formation of abstract analytical and dynamic characteristics of the circuit and its driving exo-systemic forces to subjectlevel behavioral explanations of the economic systems of various sizes, operating and developing on the basis of motivated targeted activities of all their subjects.

Identification of patterns of coordinated, focused motivational activities of all economic actors, based on knowledge of the factors of production efficiency of all kinds of goods, presupposes the existence of a common institutional and evolutionary economics. That is the theory of self-organization of the capitalist economy, in which a backbone category is the "organization of the macroeconomic order», reflecting the interaction of two processes: spontaneous market and subjectorganizational.

Competition policy involves two groups of methods: active, aimed at creating and enhancing competition in markets, and protective, designed to prevent its limitations. The difference between active and protective methods of competition policy from the viewpoint of impact on the behavior of market participants is that the former makes competition more profitable, while the latter reduces the attractiveness of its limitations. The proposed distinction may be useful: in fact, if active methods are aimed at ensuring that the incentives compete successfully suppressing the desire to limit it, protective methods are used as a tool to suppress the focus, which is on the application of sanctions [1].

The relevance of the chosen research topic explains the process of domination of large transnational capital in today's global economy. This domination deforms significantly the competitive mechanism of market selfregulation and necessitates the active participation of the state as an institutional entity in organizational support of the competitive market in the organization of capitalist production [2].

There are differences in assessing the value of the state's participation in economic life. In all areas of economic theory is a general recognition of the institutional and legal instruments of state regulation in the commoditymoney form of macroeconomics organization. Protectionist policies as a function of the state were recognized by early mercantilism theory. The social contract theory of the state acts as the guarantor already privately owned. Classical political economy narrows the role of the state to ensure a social order, development of infrastructure, maintenance of science.

The first function of the state as a guarantor of the «economic order» was justified in German ordoliberalism theory: the main function of the state consists in the use of political power to create conditions of fair competition, i.e. holding a competition protection policy. In the future State shall different range of economic policies.

A retrospective analysis of the development of economic theory, which revealed the regularities of the formation of a new economic «pro-competitive order» category. The first theoretical model of the competitive market order, designed by classics of the ordoliberalism, was built without considering the peculiarities of reproduction of cognitive capital, therefore the expanded reproduction of the total national capital bore an extensive character.

\footnotetext{
a Corresponding author: elena.rojdestvenskaya@gmail.com
} 
The concept of the knowledge economy is linked with the emergence of a new group of economic relations of production and the use of scientific and technological knowledge, which led to the emergence of new forms of capital - cognitive.

The transition to the intensive type of reproduction of the national capital is possible only with advance development of its cognitive form that suggests a system of public support for which only antitrust institutional regulation becomes insufficient.

Thus, the transition of capitalism to the stage of innovation development requires significant changes in the competitive-market mechanism in the direction of the transformation of the institute pro-competitive order.

Laws of formation of this institute in the capitalist economy based on knowledge determined the content of the theme of this study.

\section{Materials and methods}

The hypothesis of the study is based on the idea of an evolutionary theory. Its main idea is to prove the existence of an objective need to institute procompetitive order of the economy based on knowledge, necessary for long-term sustainable economic development.

The general theoretical basis of this study is the concept of the order policy. This approach is complemented by the institutional-evolutionary theory and the theory of knowledge economy. In the formation of pro-competition policy concepts used by the methods of the institutional approach [3].

The methodological and theoretical basis of the paper are scientific concepts of public administration and implementation of pro-competitive regulation in modern society. The basic concept of consideration of the antimonopoly policy is the understanding of the competition as a sign of such policy, caused by the economic, not legal value [4]. The change of the economic essence of the competition is reflected in the state approach to regulation of the imperfect market [5]. Imperfection of the market self-regulation creates the need for public intervention to compensate for «market failures».

The institutional theory is the most applicable in the research of interaction of economic subjects, formations of bases of the competition, the place and a role of the state in development of economy of knowledge.

\section{Results and discussion}

Terminological continuity with ordoliberalism theory is stored in the definition of the «pro-competitive order» category. Under the category of «order» we understand a deliberate institutional organization of the scope of economic relations. In other words, the «order» is a systemically important institutions sphere of economic, political and social relations.

The category of the "pro-competitive order» is defined as the systemic relations, including the mechanism of oligopolistic pricing in the commodity markets, targeted pro-government policy aimed at stimulating innovation activity of all subjects of the knowledge economy with a limited increase in the level of concentration and centralization of capital.

Currently, the US and EU take into account the changing nature of industrial relations during the antimonopoly regulation. Changing the content of the protection mechanism of the institute competitive market is reflected in the presence of the pro-competitive element in the system of government measures.

State regulation of the competitive market order becomes a stable institutional structure of the economy.

The accepted state decisions on antitrust regulation have an impact on the international competitiveness of the national economy, the growth of social welfare.

In an economy, based on knowledge, competition policy is transformed into «pro-competitive» - a policy of state paternalism.

The pro-competitive order is realized through the institution as a set of specific rules, norms, mechanisms and forms of interaction (figure 1). Such an understanding of the organization of economic relations is presented in the works of D. North [6], but the element of deliberate government action does not reflect what is considered in the works of ordoliberalism supporters. It is advisable to use the term «pro-competitive order» in the description of a new economic category, as this is a part of the set of cognitive organization of industrial relations, through which market competition is supported.

Changing the type of relations of production and the type of economy, and therefore, the role of the state is transformed into a state-paternalistic regulation forms of economic activity based on the priority of the production and use of scientific knowledge.

The pro-competitive order comes as a special form of the institutional capital system of the national capital, representing the institutional capacity of the economy based on scientific knowledge.

Consideration of the mechanism of implementation of the «pro-competitive order» should be as an institution of knowledge economy, understanding the set of rules, norms, mechanisms and forms of cooperation, aimed at providing a new competitive market order in the knowledge economy.

The pro-competitive order provides institutional capital accumulation of the knowledge economy.

The pro-competitive order consists of a system of formal and informal norms and rules, as well as organizational imperfectly competitive market structures (fig. 1).

The system of informal rules and norms of competitive market behavior includes the traditions, conventions, habits, following which does not require a state-legal guarantee.

The whole set of formal rules and regulations is a system of the national and international economic law. Support and promotion of fair competition requires active pro-competitive regulation.

Organizational structures are all economic agents, including the state as the guarantor of support of fair market competition and the subject of its institutional 
support. In addition to legal provision, the state satisfies the need for the formation and implementation of the protectionist competitive market (pro-competitive) policy.

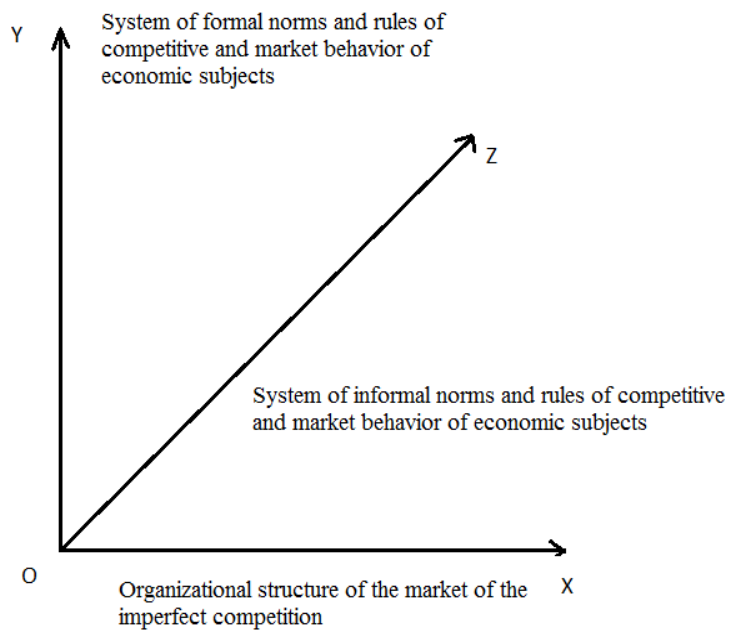

Fig. 1. The structure of the pro-competitive order institute. Compiled by the author.

Self-regulation of the social system (including economic) is possible through the rules, norms and other institutions; in German literature it is the general concept of «order». In economic theory, the category of the "competitive market order» was introduced by the founder of the German neoliberalism, W. Eucken, [7] to secure the existence of a single economic complex, including market, market competition and the system of state support for the economy. He believed that the function carried out by active government policy is the protection of free market competition, regulation of companies in the industries operating in the "Central managed order. ॥

The pro-competition policy is aimed not only at preserving and maintaining, but also at protecting fair competition.

In the knowledge economy the main purpose of the pro-competitive policy is to stimulate incremental values based on the accumulation of advanced cognitive capital.

Antitrust, transformed into pro-competitive, is a tool to ensure a free market pricing and the free development of business in all its organizational and legal forms in terms of the knowledge economy (Table 1).

The pro-competitive order of the economy based on knowledge, does not preclude the freedom of economic activity. On the contrary, it contributes to its implementation, as competition in its spontaneity does not act under the influence of the process of monopolization by the desire of the dominant firms to maintain its leadership position, which hinders sustainable development of the knowledge economy in the future.

The state acts as a guarantor of fair competition and the formation of regulatory mechanisms through a procompetitive policy tool.

The concept of the pro-competition policy recognizes the objective possibility of reaching a temporary monopoly position on the basis of competitive advantage in terms of technology as an essential performance. Typically, this technology is the result of cognitive capital investment. The recognition of this possibility differentiate the pro-competitive policy from «antitrust policy» which uses a structured approach to competition regulation (definition of the limit of the market share).

Table 1. The categories «competitive order» and «procompetitive order». Compiled by the author

\begin{tabular}{|c|c|c|}
\hline Structure & $\begin{array}{l}\text { «Competitive and } \\
\text { market order»: } \\
\text { category }\end{array}$ & $\begin{array}{l}\text { «Pro-competitive } \\
\text { order»: category }\end{array}$ \\
\hline $\begin{array}{l}\text { Type of } \\
\text { economy }\end{array}$ & $\begin{array}{l}\text { Social market } \\
\text { economy }\end{array}$ & $\begin{array}{l}\text { Socially-oriented } \\
\text { economy based on } \\
\text { knowledge }\end{array}$ \\
\hline $\begin{array}{l}\text { Type of } \\
\text { industrial } \\
\text { relations }\end{array}$ & $\begin{array}{l}\text { Real-capitalist } \\
\text { production relations }\end{array}$ & $\begin{array}{l}\text { Cognitive-capitalist } \\
\text { production relations }\end{array}$ \\
\hline Subject & $\begin{array}{l}\text { Efficient allocation } \\
\text { of scarce economic } \\
\text { goods on the basis of } \\
\text { imperfect market } \\
\text { competition }\end{array}$ & $\begin{array}{l}\text { Socio-effective } \\
\text { state-protectionist- } \\
\text { competitive market } \\
\text { allocation of goods }\end{array}$ \\
\hline $\begin{array}{l}\text { Organizatio } \\
\mathrm{n} \text { of the } \\
\text { system of } \\
\text { industrial } \\
\text { relations }\end{array}$ & $\begin{array}{l}\text { Spontaneously- } \\
\text { competitive market } \\
\text { allocation of } \\
\text { productive resources } \\
\text { and consumer goods }\end{array}$ & $\begin{array}{l}\text { Public-protectionist } \\
\text { competitive market } \\
\text { allocation of capital } \\
\text { and intellectual } \\
\text { resources }\end{array}$ \\
\hline $\begin{array}{l}\text { Dominant } \\
\text { market } \\
\text { structures }\end{array}$ & $\begin{array}{l}\text { Perfect and } \\
\text { imperfect } \\
\text { competition }\end{array}$ & $\begin{array}{l}\text { Institutional } \\
\text { adjustment } \\
\text { «creative» } \\
\text { competition }\end{array}$ \\
\hline $\begin{array}{l}\text { Functions } \\
\text { of the state }\end{array}$ & $\begin{array}{l}\text { 1. Effective use of } \\
\text { big capital (the } \\
\text { application of } \\
\text { software in the } \\
\text { industry is most } \\
\text { cost-effective) } \\
\text { 2. State regulation of } \\
\text { competition } \\
\text { (antitrust) }\end{array}$ & $\begin{array}{l}\text { 1. Promoting } \\
\text { innovation and } \\
\text { development of } \\
\text { cognitive capital (in } \\
\text { the manufacturing } \\
\text { process to ensure } \\
\text { the application of } \\
\text { cognitive capital) } \\
\text { 2. Public- } \\
\text { protectionist } \\
\text { regulation of } \\
\text { industrial relations } \\
\text { system }\end{array}$ \\
\hline $\begin{array}{l}\text { The form of } \\
\text { realization }\end{array}$ & $\begin{array}{l}\text { Stable economic } \\
\text { policy }\end{array}$ & $\begin{array}{l}\text { The pro-competition } \\
\text { policy }\end{array}$ \\
\hline $\begin{array}{l}\text { Scientific } \\
\text { substantiati } \\
\text { on } \\
\text { represented } \\
\text { in the } \\
\text { works }\end{array}$ & $\begin{array}{l}\text { W. Eucken, W. } \\
\text { Röpke, F. Boehm, } \\
\text { A. Müller- } \\
\text { Armakom, J. } \\
\text { Lampert, Friedrich } \\
\text { Hayek, V.P. Gutnik } \\
\text { and etc. }\end{array}$ & $\begin{array}{l}\text { D. North, J. } \\
\text { Hodgson, J. } \\
\text { Schumpeter, S.B. } \\
\text { Avdasheva, V.L. } \\
\text { Makarov, V.V. } \\
\text { Radaev, V.S. } \\
\text { Tsitlenok, A.E. } \\
\text { Shastitko and etc. }\end{array}$ \\
\hline
\end{tabular}

Implementation of the competition policy of the state is carried out through the use of existing regulatory instruments and through the creation of new ones. The mechanism for implementing of the pro-competitive policy is two interconnected process elements:

I. The use of the existing legal framework, the practice of law enforcement, evaluation results of economic entities reactions regulating effect. Institutionally, the system is designed as a state anti-monopoly measures. 
II. Evaluation of the effectiveness of internal and external pro-policy results. Foreign efficiency is manifested in the overall impact on the competitive environment and social welfare, interior - the ratio of «input-output». This item is not issued as standards of economic rights.

State pro-competitive policies in the countries of becoming a knowledge economy based on the development of antimonopoly legislation. However, the absence of developed and approved performance in propolitics creates the possibility of taking wrong decisions. Wrong decisions made by public bodies to protect and promote fair market competition, reduce the efficiency of all participants in the economic system.

\section{Conclusion}

A state, as a subject of market transactions, provides strategic procurement, strategic places orders, generates a tax system and develops terms of benefits and sanctions. A state pro-competitive policy becomes an institutional link mechanism of pricing, a way to overcome the «market failures».

It is proved that the development and implementation of the competition policy of the state are a form of implementation of the pro-competitive order of the institute. The content of the category of the «procompetitive policy» is based on the assumption of the possibility to achieve a temporary technological monopoly.

The effectiveness of antitrust policy will depend on the macroeconomic effectiveness of the state's economy. Not only the market mechanism is controversial, but also a system of measures for overcoming these contradictions also has its flaws and imperfections.

In the antitrust policy there is a shift from the concept of the subject-behavioral approach to systemicfunctional (impact on the competitive environment as a whole, rather than on individual subjects of the market).

Pro-competitive policies, in contrast to antitrust keep tools and basic principles in any phase of the economic cycle. The structure of the Russian economy and external trade barriers increase the need for the formation of pro-competitive policy framework.

The state is the guarantor of the reproduction of market competition, aimed at ensuring the priority of satisfaction of cognitive capital needs. It takes responsibility for ensuring the sustainability of institutional innovation orientation of market competition.

The Institute of the compensation of administrative support is formed, while spontaneous reproduction potential of market self-regulation occurs in response to innovation and quasi-monopolistic market structure needs.

The founders of the German ordoliberalism introduced the category of a "competitive market order»" to secure the existence of a single economic complex, including market, market competition and the system of state support of the economy. The experience of countries transiting to a knowledge-based economy, suggests a transformation of the economic functions of the state in the institution of the pro-competitive order designed to shape and implement a long-term pronational economic policy consisting of two areas of regulation:

1. Innovation and Production (cognitive)

2. Liberal market (antitrust).

The pro-competitive order arises from the interaction of market and socio-regulated power to ensure the unity of the process of self-regulation of the economy, based on scientific knowledge. The pro-competitive order provides a long-term strategy through a pro-equilibrium system, creating conditions for its subsequent structural changes.

Protection of the expanded reproduction of the economy, based on scientific knowledge, is the main task of the Institute of the pro-competitive order. Extended reproduction of cognitive capital ensures sustainable development and the achievement of macroeconomic equilibrium of the system.

The pro-competitive order is the whole set of formal and informal rules, regulations, organizational structures, regulating the behavior of all economic agents and their interactions.

The transition to an intensive type of reproduction of the national capital is possible only with advanced development of its cognitive form that suggests that a system of public support for a single antitrust institutional regulation is not enough.

Thus, the transition of capitalism to the stage of innovation development requires significant changes in the competitive-market mechanism in the direction of the transformation to the pro-competitive order institute.

\section{Acknowledgment}

The research is executed on the basis of Tomsk Polytechnic University with the financial support of the Ministry of Education and Science of the Russian Federation within performance of scientific research works on the project «Assessment and Improvement of Social, Economic and Emotional Wellbeing of Elderly People», contract No. 14.Z50.31.0029

\section{References}

1. A. Shastitko, S. Afontsev, S. Plaksin, Problems of Economics, 1, (2008)

2. C. Shapiro, OECD Science Technology and Industry Working Papers, 2002/11 (2002)

3. E.M. Rozhdestvenskaya, V.S. Citlenok, J. Vestn. Tom. gos. un-ta, 390, (2015)

4. K. Totev, J. Hozyajstvo i pravo, 2, 61-68 (2011)

5. E.P. Vasilev, I.N., J. Sovremennaya konkurentsiya, 2(8), (2008)

6. D. North Structure and Change in Economic history, N.-Y, Norton (1981)

7. W. Eucken, Osnovnyje prinzipy ekonomieskoj politiki [Grundsätze der Wirtschaftspolitik], M, Progress (1995) 